interviewing witnesses, preparing legal arguments and briefs and in certain circumstances, by making court appearances of a routine nature. The responsibility of the student worker would not end with his referral of the case to Legal Aid, but with the consent of the appointed lawyer the student would be prepared to do a large amount of the "leg work" of research, etc., for the lawyer, thus removing the burden from a busy professional man and ensuring the case is given the attention it deserves. From the student's point of view, he could gain valuable experience in the administration of justice, but beyond this the main benefit to be gained is through a personal contact with individuals, viewing them and their relationship to the law. This latter benefit adds a certain reality to the study of law by placing the theory into a living, social context. In the opinion of the summer workers the value of this experience for students can hardly be overstated. Should the results obtained in the future continue to be as striking as those obtained in the comparatively short time the project has been functioning the value of its operations to the public are self-evident.

-Rolly Laing*

-Donna Koziak**

- Of the third year class. Faculty of Law Summer Assistant with the Student Legal Services Project, 1969.

** Of the second year class. Faculty of Law Summer Assistant with the Student Legal Services Project, 1969.

THE INCOME TAX ACT, R.S.C. 1952, C. 148 AS AMENDED, S. 126, 126A. - SOLICITOR-CLIENT PRIVILEGE - OTHER PROFESSIONAL ADVISORS OF THE TAXPAYER WITHOUT PRIVILEGE. -MISSIAEN v. M.N.R. ${ }^{1}$

The question of privilege with respect to production of documents on the part of professional advisers of taxpayers, as represented by case of Missiaen v. M.N.R. is perhaps timely for two reasons: firstly, because of the apparent increasing use of search and siezure weapons by the Department of National Revenue and secondly, as the clarion call in revenue matters currently appears to be "equity and neutrality" it would not be inappropriate to examine the present law from that view point.

Section 126 of the Income Tax Act" sets out the powers of the Minister of National Revenue and his officials to undertake a search and seizure or to require the production of documents. While this is beyond the scope of the present topic suffice it to say that these are very broad in nature and go considerably beyond parallel provisions in the Criminal Code. ${ }^{3}$ The Minister may for any purpose related to the enforcement or administration of the Income Tax Act virtually engage in a cross-Canada "fishing expedition" and in so doing "empty the offices of the chartered accountant and of the barristers of all

1 (1968) 68 D.T.C. 5039.

2 R.C.S. 1952, c. 148 as amended.

3 See Canadian Criminal Code, S.C. 1953-54, c. 51, as amended. ss. 429-432. 
things which may afford evidence as to violation of any provisions of the Income Tax Act."4 As to the necessity of such stringent provisions, weighing the need for efficient collection of the public revenue with individual freedoms and safeguards, reference is made to the paper delivered by Prof. Huberman to the 1968 Canadian Bar Association Convention $^{5}$ which will no doubt be reported in their proceedings in due course.

Virtually the only limitation on the snooping ability of the Minister is that provided by section $126 \mathrm{~A}$ which substantially keeps alive the common law right of solicitor-client privilege. For the purposes of the Act it is defined as follows:

"solicitor-client privilege" means the right if any that a person has in a superior court in the province where a matter arises to refuse to disclose an oral or documentary communication on the ground that the communication is one passing between him and his lawyer in professional confidence, except that for the purposes of this section and accounting record of a lawyer, including any voucher or cheque shall be deemed not to be such a communication.

The balance of the section is merely procedural in nature providing for sealing of disputed documents, delivery to a custodian, usually the sheriff or other semi-judical officer pending ultimate disposition by a superior court or Exchequer Court judge as to the existence of the privilege.

Section 126A was first enacted in 1956 prior to which time the position at common law applied. The first case considered thereunder was not heard until 1961.' However, reading between the lines in that case it would appear possibly it was the notary himself who was being investigated rather than his clients. There was then one reported decision in $1966^{\circ}$ followed by six in $1968 .^{\circ}$ If the increasing incidence of reported decisions is any indication of the use which is being made of the seizure provisions it is then timely that they be reconsidered. Indeed it is likely that with the use of more sophisticated compliance techniques and increased interest with which the Revenue are regarding tax planning and avoidance schemes in general this weapon may become steadily more popular.

It is also suggested that it is appropriate at this juncture to reconsider the position of privilege generally with a view to elevating tax counsellors other than solicitors eg. chartered accountants, actuaries, insurance people and management consultants into an equally protected position. This will be argued at some length later.

As to the state of the existing law, it would appear from the decided cases that Canada has not changed, to any degree, the old English position as it grew up in the courts of Chancery. Wilson, C.J. speaking as to the British Columbia position in $R e K a s k,{ }^{10}$ specifically states this. It also appears to have been implicitly assumed in Lagasse v. A.G.

\footnotetext{
4 David Huberman, Search and Siezure under the Income Tax Act, Paper presented to Convention of the Canadian Bar Assoclation September 4. 1968

Id.

6 Income Tax Act, R.S.C., c. 148, as amended S.C. 1965, c. 18, s. 26; s. 126A (1) e.

7 Lagassé v. Deputy A.G. of Canada (1961) D.T.C. 1025.

8 Re Kask (1966) 66 D.T.C. 5374. 9. M.C. 5039; Re W. B. Milner, Atkins \& Durbrow (Erie)

Ltd. (1968) D.T.C. 5261; Re David Sokolov (1968) 68 D.T.C. 5266; Re Edward Evans (1968) 68 D.T.C. 5277; Re Goodman \& Carr v. M.N.R. (1968) 68 D.T.C. 5288, (No. 2) 68 D.T.C. 5310; Re Modern Film Distributors Ltd., Rolla Burdick Andrus and Romar Films Ltd. (1968) 68 D.T.C. 5349

10 (1966) 66 D.T.C. 5374.
} 
Canada ${ }^{11}$ to be the law of Quebec. The rest of Canada has adopted substantially the same practice. The essential points required to raise a solicitor-client privilege are as follows:

1. The privilege is that of the client, not the solicitor. However until the client waives the privilege the solicitor is bound to claim it and is in breach of duty if he does not do so. ${ }^{12}$

2. The documents or knowledge must have arisen in the course of a professional relationship. However the bounds of this relationship will be construed liberally. ${ }^{13}$ (Minter v. Priest [1930] AC. 558 at 568 per Lord Buckmaster)

3. There must be no fraudulent or illegal purpose underlying the transaction in connection with the advice was sought, there being then no bona-fide professional relationship. ${ }^{14}$

4. There need not be a prospect of litigation in view where the communication is between solicitor and client directly. However for a communication between third parties [ie. accountants] and the solicitor to be privileged it must be made with a view to litigation and also the third party must have intended the communication to be submitted to the solicitor so that the solicitor may advise the client. The third party himself may not render independent advice to the client. ${ }^{15}$

It is desired at this point to set out several minor points in which our practice differs from the English, at least in Income Tax matters. By section 126A (14) the solicitor must give to the Minister his client's address in order that the Minister may communicate with him with a view to waiving the privilege. The common law practice did not require this. ${ }^{16}$ Secondly, by section $126 \mathrm{~A}$ (1)e an accounting record of the solicitor is not privileged, contrary to the position at common law.

The courts however, in so far as they are able, appear to have taken the broadest possible view of the privilege. In $R e E v a n s^{17}$ a bill of costs between solicitors was not considered to be an accounting document in as much as its production may show the nature of the instructions taken and advice given, broadening earlier decisions where production of accounts was ordered. Also in Re David Sokolov, ${ }^{18}$ Matas, $\mathrm{J}$. in the Manitoba Court of Queens Bench purported to broaden rule (4) above, saying that there should not have to be litigation in view for the possibility of privilege respecting communications passing between solicitors and third parties, if the other criteria of privilege were met. This particular decision is of some importance and will be more fully adverted to at a later point.

Re David Sokolov ${ }^{18}$ presented a typical selection of documents involved in a sophisticated tax avoidance scheme. The bulk of the documents were characterized under the foregoing principles with no difficulty. The papers on which it is intended to concentrate for present purposes are two memoranda from the accountants, as well as one

11 (1961) 61 D.T.C. 1075.

12 Anderson v. Bank of British Columbia [1876] 2 Ch.D. 644 at 649, per Jessel, M.R.

13 Minter v. Priest [1930] A.C. 558 at 568 , per Lord Buckmaster.

14 The Queen v. Cox and Raition (1844) Q.B.D. 153 at 188, per Stephen, J.

14 The Queen v. Cox and Raitton (1844) Q.B.D. 153 at 188,
15 Anderson v. Bank of British Columbia [1876] 2 Ch.D. 644.

16 Wheeler v. LeMarchant (1881) 17 Ch.D. 675 .

17 (1968) 68 D.T.C. 5277 .

18 (1968) 68 D.T.C. 5266.

19 Id. 
letter from the accountants to the client setting out certain recommendations with respect to the proposed scheme. It was found as a fact that the two memoranda were a summary of a meeting between the accountants, the client and a special tax counsel to discuss the proposed reorganization and that the accountants acted as agents of the client in transmitting the memos to the solicitor in order that he could in turn tender advice to the client. These were held to be privileged as it once was held that third party communications should no longer be required to be respecting proposed litigation, they met the other criteria set out. The copy of the letter to the client from the accountants was not privileged as it tendered their advice, and was not submitted to the solicitor in order that he could render advice to the client.

Similar results were obtained in the earlier Alberta case of Missiaen v. M.N.R., where copies of an accountant's report to the client in the possession of the solicitor were not privileged for the same reason. In that case, presumably as in others, the accountants' files, (in respect of which no privilege exists), were also seized.

In Missiaen, Primrose J. in the Alberta Supreme Court commented as follows on the position of the accountant:

"While no claim was made to privilege of the correspondence between the client and the chartered accountant acting for the Applicants, and there is no provision in the Income Tax Act to provide such privilege, it would appear there is some merit in such a claim. . . . Certainly, the chartered accountant with the client is in an analogous position to a solicitor and his client and it is rather strange that no privilege is accorded or claimed in such circumstances."21

In both the above cases as well as in Re Goodman and Carr the Revenue Department apparently suggested that tax avoidance schemes amounted to fraud or illegality in a broad sense so that on ordinary principles the claim to privilege is vitiated. In aid of this argument section 138 (6) was used. This section provides that for the purposes of that section (actions by the Treasury Board to counteract tax avoidance) an action may be regarded as improper although not illegal. In each case this contention was given short shrift and was rejected out of hand, presumably settling the law on this point. To what extent the rather abbreviated judgment of Dryer J. in Re Modern Film Distributors Ltd., Rolla Burdick Andrus and Romar Films Ltd.,"3 may be taken to go against this position can not be ascertained by the report of the judgment, but the better view, at least, is that avoidance, as opposed to evasion maneouvres (for example Re Income Tax Act and Milner ${ }^{24}$ does not result in loss of solicitor-client privilege.

Thus it appears the solicitor is relatively safe and may freely correspond with his client, leave as many notes on his files as he wishes and generally act as he would in any other matter in which his opinion had been sought. The other professional advisers of the client on the other hand may not safely and with the best interests of the client at heart act so freely. Under the present law if they expect to avoid production of possibly compromising documents at their offices they

20 (1968) 68 D.T.C. 5039.

20 (1968) 68 D.T.C. 5039 . 504 at 5041

22 (1968) 68 D.T.C. 5288 and 5310

$22(1968) 68$ D.T.C. 5288 . 23 .

24 (1968) 68 D.T.C. 5261 . 
must avoid retaining files or even copies of their own reports and memorandums. Secondly, they must decline to communicate with their client directly (except where the client is a mere conduit for passing the matter on to the solicitor for his information so that he in turn may advise the client). This, it is submitted, would be a dangerous fact to have to establish in the ordinary case. Rather, they must suggest to the client that he have his solicitor request the report of them and submit it to him.

The need of the Minister for a full account of various transactions that have taken place can not be gainsaid; otherwise there would be no basis on which the transactions could properly be assessed. It is quite another thing to say that he should be able to read a person's mind and know why and for what reason certain proceedures were instituted while available alternatives were not. The actual transactions will often be a matter of public record, where they are not, the appropriate documents and agreements should be produced. The subject matter of seized documents is generally not of this character, rather they are a logbook of the vacillations, reasoning and inner thoughts of the collective entity planning the transaction. Quite rightly the taxpayer and his advisors may attempt to shield these deliberations from the inquiring eye of the Minister and let the facts speak for themselves.

Referring to the steps the client and his advisor group must go to accomplish these ends it is obvious that carried to its logical extension the procedures are ridiculous. Considerable man hours would be wasted, normal business procedures must be substantially diverged from and the participants put to substantial inconvenience. Accountants and other third party advisors, if later asked to support their opinions, could not easily do so, being unable to safely retain working notes etc. and thereby laying themselves open to possible negligence charges etc.

Yet the alternative is not much more attractive. Allowing the Revenue Department, in essence, to be privy to all discussions regarding a client's affairs is hardly calculated to strengthen the client's position where the possibility of assessments being raised under the discretionary sections or other areas where the tests of "bona-fide; arms length; good business purpose" etc. abound. The effects of this are not likely to be reduced where the Minister has a large stock of documents to sift through, choosing those he desires to enter in evidence. The rest of the pile is in many cases not open to the taxpayer to tender being of a self serving nature and hence inadmissible.

Another reason against continuation of the present rules is the concepts of equity and neutrality fully espoused by the Carter Commission $^{25}$ and even the government. ${ }^{20}$ It is submitted this should apply to procedural as well as substantive matters; it should apply as well to the considerations a taxpayer must have in mind when choosing his advisers as well as the business transactions he feels it to his advantage to enter into. The present law provides definite incentives to choosing

25 Canada, Heport of the Royal Commission on Taxation, 1966.

26 See the Budget Resolutions and Speech of Mr. Benson, Minister of Finance, Tuesday, October 22, 1968: 113, H. of C. Deb. No. 28, 1686; Income Tax Act Resolution, Para. 7. 
a solicitor as chief tax consultant and letting him consult with such others as he feels advisable (or is instructed by his client to approach) as only then will the Minister's snooping ability be held at bay. The taxpayer's solicitor may safely report to him, his accountant may not. Where is the equity, where is the fairness? Just as life insurance formerly was a government encouraged investment so now are lawyers government encouraged tax advisers to the exclusion of accountants and others, regardless of competence.

The general attitude toward solicitor privilege in Canada was probably fairly stated by Molloy, Co. Ct. J. in Taylor v. Lailey and Filbert. ${ }^{27}$ The context was vehicle accidents where the insurer first employs an adjuster and only later a solicitor. Dealing with statements made to an adjuster which were desired to be privileged, claiming the adjuster acted as the agent of the solicitor, the learned judge said:

For reasons of efficiency or economy insurers generally first seek the assistance of adjusters to investigate and negotiate settlement of claims and consult a solicitor only later, when the advisability of doing so is clearly indicated. I do not think they can complain because the advantages of employing an adjuster do not include the benefit of privileged communication which results from employing a solicitor, a benefit which can be ensured by referring claims to a solicitor from the outset leaving him to employ such assistance for investigation as he may require.

The effect of this attitude is to tend to divert to the legal profession work that they may not otherwise have received or that they are not best fitted to do, but only in that way may the client protect the privacy of his information.

When the present results of the doctrine are compared with the original purpose, the desired corrections are obvious, not only in tax matters but over the whole field. In order to obtain proper legal advice it was considered necessary to allow the client to put his solicitor in full possession of the facts and circumstances being fully confident that his confidences would be respected. Originally this was restricted to consultations in expectation of litigation and of course the same privilege was extended to communications with counsel. Later confidences resulting from any professional consultation became privileged. In those days if privilege was allowed legal advisers sufficient protection had been given; in the less complex days of yesteryear a man of affairs would require only two consultants-his legal advisor and his spiritual advisor. Today this is no longer so, especially in revenue matters where the solicitor is only one member of the planning team as Primrose, $\mathrm{J}$. noted. ${ }^{28}$ Not only is the accountant more often than not the chief financial and tax consultant to his client, but he is also able, if he wishes, to represent him before the Tax Appeal Board as an advocate.

It is therefore suggested that a taxpayer is just as entitled to lay his affairs before an accountant or other tax advisor for the purpose of receiving professional advice, with the expectation that his confidences will be kept, as he is to deal with his lawyer for the same purpose.

Even if the judicary wished to extend the doctrine, in the face of settled law of centuries and the express wording of the Income Tax

27 (1959) 27 W.W.R. 257 at 267.

28 see n. 21 above. 
Act, they would be unable to do so. This is especially so since the Act provides that the adjudication be of a summary nature with the determination of the trial judge as a persona designata being final, thereby precluding consideration by appellate courts and the Supreme Court of the question. Thus they could not be expected to change the present law and the possibility of judical comment thereon and the greater weight attached to dictums of the higher courts would not be possible here.

Only Parliament can provide the remedy and this it is unlikely to do, the Minister of National Revenue being not likely to be favourably disposed to voluntarily giving up one of his investigative tools. Both the Canadian Institute of Chartered Accountants and the Canadian Tax Foundation are considering making recommendations to the government in this respect. Unfortunately, their prospects of success appear to be dim.

-ROBERT M. LEWIS*

* B.Comm., LL.B. of the 1969 graduating class.

\section{THE EX-PARTE INJUNCTION IN MATRIMONIAL CASES}

It is becoming increasingly frequent in suits for Divorce or Judicial Separation, where the claim is based on allegations of cruelty, for the wife, who is Plaintiff or Petitioner in such proceedings, to apply for and obtain an Ex-Parte Injunction immediately the Statement of Claim or Petition has been issued and for the Injunction to be served on the Defendant or Respondent husband with the originating process. The form of the Injunction, in the Judicial District of Calgary at least, is usually as follows-

(i) The husband is restrained from entering or visiting the matrimonial home.

(ii) The husband is restrained from molesting or interfering with the wife (and sometimes the children as well).

(iii) It is further ordered that "any Police Officer to whom any breach of the terms of this order by the Defendant or anyone acting on his behalf is indicated" shall arrest the Defendant or any such person and cause him to be brought before the court (or, in at least one case I have seen "a Judge of the Appropriate Court") to be dealt with according to law.

(iv) Leave is given for the Defendant or Respondent to apply on forty-eight hours notice to vary or set aside the order.

Oliver Wendell Holmes once defined law as "nothing more than a prediction of what the courts or judges will do in any given set of circumstances." If this is a correct definition, it seems that many of the text books commonly used by students and practitioners are inaccurate, so far as they relate to this branch of the practice of law. For example, both Maitland, the classical student's text book on equity, ${ }^{1}$ and Atkin's Encyclopedia of Court Forms," state that the Ex-Parte Injunction, when

1 Maitland, Equity (2nd ed.), 1936.

2 Atkin, Encyclopaedia of Court Forms in Civil Proceedings (2nd ed.), 1963. 